\title{
SYNTHESIS, CRYSTAL STRUCTURES AND ANTIBACTERIAL ACTIVITIES OF BENZOHYDRAZONE DERIVATIVES FROM 4-DIETHYLAMINOSALICYLALDEHYDE
}

\author{
ZHIGANG WANG ${ }^{1, \infty}, F E N G Z H I^{2, \infty}$, RONG WANG ${ }^{2}$, LIAN XUE ${ }^{2}, Y I Z H A N G^{2}$, QIANG WANG ${ }^{2}$, YI-LIN YANG ${ }^{2, *}$ \\ ${ }^{I}$ Department of Respiratory Medicine, Third Affiliated Hospital of Soochow University, Changzhou 213000, P. R. China; \\ ${ }^{2}$ Modern Medical Research Center, Third Affiliated Hospital of Soochow University, Changzhou 213000, P. R. China \\ $\infty$ These authors contributed equally to this work. \\ (Received: November 23, 2012 - Accepted: January 14, 2013)
}

\begin{abstract}
A series of three new benzohydrazone compounds, $\mathrm{C}_{18} \mathrm{H}_{21} \mathrm{~N}_{3} \mathrm{O}_{3}$ (1), $\mathrm{C}_{19} \mathrm{H}_{23} \mathrm{~N}_{3} \mathrm{O}_{3}$ (2), and $\mathrm{C}_{18} \mathrm{H}_{20} \mathrm{ClN}_{3} \mathrm{O}_{2}$ (3), derived from the condensation of 4-diethylaminosalicylaldehyde with 2-hydroxybenzohydrazide, 4-methoxybenzohydrazide, and 4-chlorobenzohydrazide, respectively, in methanol, were prepared. The compounds were characterized by elemental analysis, IR spectra, ${ }^{1} \mathrm{H}$ NMR spectra, and single crystal X-ray diffraction. Compound 1 crystallizes in the monoclinic space group $P 2$ with unit cell dimensions $a=6.2656(6) \AA, b=21.873(2) \AA, c=6.6362(7) \AA, \beta=114.025(2)^{\circ}, V=830.70(15) \AA^{3}, Z=2, R_{1}=0.0323$ and $w R_{2}=0.0784$. Compound 2 crystallizes in the monoclinic space group $P 2 / c$ with unit cell dimensions $a=13.8966(17) \AA, b=13.1402(15) \AA, c=9.8043(12)$ $\AA, \beta=90.768(2)^{\circ}, V=1790.1(4) \AA^{3}, Z=4, R_{1}=0.0670$ and $w R_{2}=0.1671$. Compound 3 crystallizes in the triclinic space group $P$-1 with unit cell dimensions $a$ $=9.884(2) \AA, b=11.781(3) \AA, c=15.990(4) \AA, \alpha=95.916(5)^{\circ}, \beta=99.520(5)^{\circ}, \gamma=104.147(4)^{\circ}, V=1760.5(7) \AA^{3}, Z=4, R=0.0698$ and $w R_{2}=0.1250$. Crystal structures of the compounds are stabilized by hydrogen bonds and $\pi \cdots \pi$ stacking interactions. The preliminary antibacterial tests against Staphylococcus aureus, Escherichia coli, Klebsiella pneumoniae, and Candida albicans were assayed.
\end{abstract}

Keywords: benzohydrazone; crystal structure; X-ray diffraction; antibacterial activity; hydrogen bonds.

\section{INTRODUCTION}

The condensation of carbonyl-containing compounds with primary amines produce Schiff base compounds bearing $\mathrm{C}=\mathrm{N}$ double bonds, which is an essential structural requirement for biological activities, especially for antibacterial, antimicrobial, antifungi, and antitumor activities. ${ }^{1-4}$ Benzohydrazone derivatives are a kind of special Schiff bases bearing $\mathrm{C}=\mathrm{N}-\mathrm{NH}-\mathrm{CO}-\mathrm{Ph}$ functional groups. As is well known, Schiff bases derived from salicylaldehyde and its derivatives have interesting biological activities. In recent years, considerable attention has been focused on the preparation and biological activities of benzohydrazone derivatives. ${ }^{5-8}$ During the search of literature, we observed that benzohydrazone derivatives have effective antibacterial activities; yet, the number of such compounds is relatively less than the usual Schiff bases. In order to investigate the crystal structures and antibacterial activities of benzohydrazone derivatives, in the present paper, 4-diethylaminosalicylaldehyde, a compound bearing lipophilic group, was used to prepare three benzohydrazone derivatives, $\mathrm{C}_{18} \mathrm{H}_{21} \mathrm{~N}_{3} \mathrm{O}_{3}(\mathbf{1}), \mathrm{C}_{19} \mathrm{H}_{23} \mathrm{~N}_{3} \mathrm{O}_{3}$

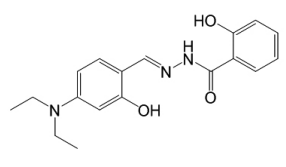

1
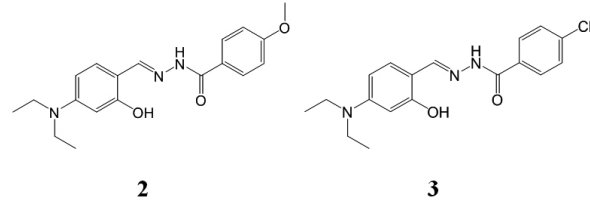

(2), and $\mathrm{C}_{18} \mathrm{H}_{20} \mathrm{ClN}_{3} \mathrm{O}_{2}$ (3).

\section{EXPERIMENTAL}

Materials and Methods: 4-Diethylaminosalicylaldehyde, 2-hydroxybenzohydrazide, 4-methoxybenzohydrazide, and 4-chlorobenzohydrazide were obtained commercially from Lancaster Research Chemicals. Solvents used were of analytical grade. Elemental analyses (CHN) were performed on a Perkin-Elmer 240C elemental analyzer. IR spectra were recorded on a Perkin Elmer Paragon 1000 spectrophotometer. ${ }^{1} \mathrm{H}$ NMR spectra were recorded on a Bruker DPX-400 instrument at $400 \mathrm{MHz}$ with tetramethylsilane as the internal reference.

Synthesis of N'-(4-Diethylamino-2-hydroxybenzylidene)-2hydroxybenzohydrazide (1): 4-Diethylaminosalicylaldehyde (1.0 mmol, 0.193 g) was added with stirring to 2-hydroxybenzohydrazide (1.0 mmol, 0.152 $\mathrm{g}$ ) in methanol. The mixture was heated under reflux for $1 \mathrm{~h}$, and cooled to room temperature. After filtration and slow evaporation in air for a few days, colorless block-shaped single crystals were formed. The crystals were collected by filtration, washed three times with methanol. Yield, $0.29 \mathrm{~g}(89 \%)$. Anal. Calcd. (\%) for $\mathrm{C}_{18} \mathrm{H}_{21} \mathrm{~N}_{3} \mathrm{O}_{3}$ : C, 66.0; H, 6.5; N, 12.8. Found (\%): C, 65.8; $\mathrm{H}, 6.5 ; \mathrm{N}, 12.9$. Characteristic IR data $\left(\mathrm{KBr}, \mathrm{cm}^{-1}\right): 3412(\mathrm{w})\left(v_{\mathrm{O}-\mathrm{H}}\right), 3183(\mathrm{~m})$ $\left(v_{\mathrm{N}-\mathrm{H}}\right), 1637(\mathrm{~s})\left(v_{\mathrm{C}=\mathrm{O}}\right), 1602(\mathrm{~s})\left(v_{\mathrm{C}=\mathrm{N}}\right) .{ }^{1} \mathrm{HNMR}$ data $(d-\mathrm{DMSO}, \mathrm{ppm}): \delta=1.14$ $(\mathrm{m}, 6 \mathrm{H}), 3.40(\mathrm{~m}, 4 \mathrm{H}), 6.32(\mathrm{~s}, 1 \mathrm{H}), 6.39(\mathrm{~d}, 1 \mathrm{H}), 6.9-7.9(\mathrm{~m}, 5 \mathrm{H}), 8.72(\mathrm{~s}, 1 \mathrm{H})$, $11.17(\mathrm{~s}, 1 \mathrm{H}), 11.56(\mathrm{~s}, 1 \mathrm{H}), 12.78(\mathrm{~s}, 1 \mathrm{H})$.

Synthesis of N'-(4-Diethylamino-2-hydroxybenzylidene)-4methoxybenzohydrazide (2) and 4-Chloro- $N$ '-(4-diethylamino-2hydroxybenzylidene)benzohydrazide (3): Compounds $\mathbf{2}$ and $\mathbf{3}$ were synthesized by the same method as that described for 1, with 2-hydroxybenzohydrazide replaced by 4 -methoxybenzohydrazide $(1.0 \mathrm{mmol}, 0.166 \mathrm{~g})$ for 2 , and by 4-chlorobenzohydrazide $(1.0 \mathrm{mmol}, 0.171 \mathrm{~g})$ for 3 . The filtrates for the two compounds were stood still in air to slow evaporate of the solvent to yield colorless block-shaped single crystals. For 2 : Yield, $0.28 \mathrm{~g} \mathrm{(82 \% ).} \mathrm{Anal.} \mathrm{Calcd.}$ (\%) for $\mathrm{C}_{19} \mathrm{H}_{23} \mathrm{~N}_{3} \mathrm{O}_{3}$ : C, 66.8; H, 6.8; N, 12.3. Found (\%): C, 67.0; H, 6.9; N, 12.2. Characteristic IR data $\left(\mathrm{KBr}, \mathrm{cm}^{-1}\right): 3403(\mathrm{w})\left(v_{\mathrm{OH}}\right), 3170(\mathrm{~m})\left(v_{\mathrm{NH}}\right), 1636$ (s) $\left(v_{\mathrm{C}=0}\right), 1602(\mathrm{~s})\left(v_{\mathrm{C}=\mathrm{N}}\right) . .{ }^{1} \mathrm{HNMR}$ data $(d$-DMSO, ppm): $\delta=1.14(\mathrm{~m}, 6 \mathrm{H})$, $3.40(\mathrm{~m}, 4 \mathrm{H}), 3.85(\mathrm{~s}, 3 \mathrm{H}), 6.32(\mathrm{~s}, 1 \mathrm{H}), 6.39(\mathrm{~d}, 1 \mathrm{H}), 7.1-7.9(\mathrm{~m}, 5 \mathrm{H}), 8.72(\mathrm{~s}$, $1 \mathrm{H}), 11.32(\mathrm{~s}, 1 \mathrm{H}), 12.40(\mathrm{~s}, 1 \mathrm{H})$. For 3: Yield, $0.31 \mathrm{~g} \mathrm{(90 \% ).} \mathrm{Anal.} \mathrm{Calcd.} \mathrm{( \% )}$ for $\mathrm{C}_{18} \mathrm{H}_{20} \mathrm{ClN}_{3} \mathrm{O}_{2}: \mathrm{C}, 62.5 ; \mathrm{H}, 5.8 ; \mathrm{N}, 12.2$. Found (\%): $\mathrm{C}, 62.6 ; \mathrm{H}, 5.8 ; \mathrm{N}, 12.3$. Characteristic IR data $\left(\mathrm{KBr}, \mathrm{cm}^{-1}\right): 3427(\mathrm{w})\left(v_{\mathrm{O}-\mathrm{H}}\right), 3162(\mathrm{~m})\left(v_{\mathrm{N}-\mathrm{H}}\right), 1638(\mathrm{~s})$ $\left(v_{\mathrm{C}=\mathrm{O}}\right), 1601(\mathrm{~s})\left(v_{\mathrm{C}=\mathrm{N}}\right) . .{ }^{1} \mathrm{HNMR}$ data $(d$-DMSO, $\mathrm{ppm}): \delta=1.14(\mathrm{~m}, 6 \mathrm{H}), 3.41$ $(\mathrm{m}, 4 \mathrm{H}), 6.31(\mathrm{~s}, 1 \mathrm{H}), 6.39(\mathrm{~d}, 1 \mathrm{H}), 7.4-8.0(\mathrm{~m}, 5 \mathrm{H}), 8.72(\mathrm{~s}, 1 \mathrm{H}), 11.51(\mathrm{~s}, 1 \mathrm{H})$ $12.82(\mathrm{~s}, 1 \mathrm{H})$.

X-ray Crystallography: Suitable single crystals of the three compounds were mounted on glass fibers for X-ray measurement. Reflection data were collected at room temperature on a Bruker AXS SMART APEX II CCD diffractometer with graphite monochromatized Mo-K $\alpha$ radiation $(\lambda=0.71073$ $\AA$ ). Crystal structures of the three compounds were solved by direct method. All non-hydrogen atoms were refined anisotropically. The amino $\mathrm{H}$ atoms were located from difference Fourier maps and refined isotropically, with $\mathrm{N}-\mathrm{H}$ distances restrained to $0.90(1) \AA$. The remaining hydrogen atoms were fixed at calculated positions and refined by using riding models. All calculations were performed using SHELX-97. ${ }^{9}$ Crystal data and details of the data collection and the structure refinement are given in Table 1. Hydrogen bonding information is given in Table 2.

Antibacterial Test: The compounds were tested for their in vitro antibacterial activities against Staphylococcus aureus var. Oxford 6538, Escherichia coli ATCC 10536, Klebsiella pneumoniae ATCC 100131 and Candida albicans ATCC 10231 strains using the paper disc diffusion method (for the qualitative determination) and the serial dilutions in liquid broth method (for determination of the MIC). ${ }^{10}$ Tetracycline was used as the reference drug. 
TABLE 1. Crystal Data and Refinement Parameters for the Compounds.

\begin{tabular}{|c|c|c|c|}
\hline Compound & 1 & 2 & 3 \\
\hline Empirical formula & $\mathrm{C}_{18} \mathrm{H}_{21} \mathrm{~N}_{3} \mathrm{O}_{3}$ & $\mathrm{C}_{19} \mathrm{H}_{23} \mathrm{~N}_{3} \mathrm{O}_{3}$ & $\mathrm{C}_{18} \mathrm{H}_{20} \mathrm{ClN}_{3} \mathrm{O}_{2}$ \\
\hline Molecular weight & 327.4 & 341.4 & 345.8 \\
\hline Crystal color, habit & Colorless, block & Colorless, block & Colorless, block \\
\hline Crystal size $\left(\mathrm{mm}^{3}\right)$ & $0.20 \times 0.20 \times 0.17$ & $0.20 \times 0.17 \times 0.15$ & $0.30 \times 0.27 \times 0.27$ \\
\hline Crystal system & Monoclinic & Monoclinic & Triclinic \\
\hline Space group & $P 2_{1}$ & $P 2_{1} / c$ & $P-1$ \\
\hline \multicolumn{4}{|l|}{ Unit cell dimensions } \\
\hline$a(\AA ́)$ & $6.2656(6)$ & $13.8966(17)$ & $9.884(2)$ \\
\hline$b(\AA)$ & $21.873(2)$ & $13.1402(15)$ & $11.781(3)$ \\
\hline$c(\AA)$ & $6.6362(7)$ & $9.8043(12)$ & $15.990(4)$ \\
\hline$\alpha\left(^{\circ}\right)$ & 90 & 90 & $95.916(5)$ \\
\hline$\beta\left(^{\circ}\right)$ & $114.025(2)$ & $90.768(2)$ & $99.520(5)$ \\
\hline$\gamma\left({ }^{\circ}\right)$ & 90 & 90 & $104.147(4)$ \\
\hline$V\left(\AA^{3}\right)$ & $830.70(15)$ & $1790.1(4)$ & $1760.5(7)$ \\
\hline$Z$ & 2 & 4 & 4 \\
\hline$D_{\text {calc }}\left(\mathrm{g} \mathrm{cm}^{-3}\right)$ & 1.309 & 1.267 & 1.305 \\
\hline Absorption coefficient $\left(\mu, \mathrm{mm}^{-1}\right)$ & 0.091 & 0.087 & 0.232 \\
\hline$\theta$ range collected $\left(^{\circ}\right)$ & $3.3-27.9$ & $2.6-24.3$ & $2.3-24.5$ \\
\hline$T_{\min }$ and $T_{\max }$ & 0.982 and 0.985 & 0.983 and 0.987 & 0.934 and 0.940 \\
\hline Reflections collected/unique $\left(R_{\text {int }}\right)$ & $4369 / 2982(0.0127)$ & $17156 / 3311(0.0407)$ & $14382 / 7318(0.0690)$ \\
\hline Data/restraints/parameters & $2982 / 2 / 224$ & $3311 / 1 / 233$ & $7318 / 6 / 463$ \\
\hline Observed reflections $[I \geq 2 \sigma(I)]$ & 2721 & 2093 & 2860 \\
\hline$R_{1}, w R_{2}[I \geq 2 \sigma(I)]$ & $0.0323,0.0784$ & $0.0670,0.1671$ & $0.0698,0.1250$ \\
\hline$R_{1}, w R_{2}$ (all data) & $0.0365,0.0818$ & $0.1105,0.1968$ & $0.1881,0.1648$ \\
\hline Goodness of fit (GOF) on $F^{2}$ & 1.037 & 1.034 & 0.916 \\
\hline Largest differences in peak/hole $\left(\mathrm{e} / \AA^{3}\right)$ & 0.102 and -0.160 & 0.632 and -0.277 & 0.175 and -0.220 \\
\hline
\end{tabular}

TABLE 2. Geometrical Parameters for Hydrogen Bonds.

\begin{tabular}{|c|c|c|c|c|}
\hline$D-\mathrm{H} \cdots A$ & $D-\mathrm{H}(\AA \hat{)})$ & $\mathrm{H} \cdots A(\AA \dot{\AA})$ & $D \cdots A(\AA ́)$ & $D-\mathrm{H} \cdots A\left(^{\circ}\right)$ \\
\hline \multicolumn{5}{|c|}{1} \\
\hline $\mathrm{O} 1-\mathrm{H} 1 \cdots \mathrm{N} 2$ & 0.82 & 1.92 & $2.642(2)$ & 147 \\
\hline N3-H3B $\cdots$ O3 & $0.90(1)$ & $1.90(2)$ & $2.643(2)$ & $140(2)$ \\
\hline $\mathrm{O} 3-\mathrm{H} 3 \cdots \mathrm{O} 2^{\mathrm{i}}$ & 0.82 & 1.87 & $2.673(2)$ & 167 \\
\hline \multicolumn{5}{|c|}{2} \\
\hline $\mathrm{N} 3-\mathrm{H} 3 \mathrm{~A} \cdots \mathrm{O} 2^{\mathrm{ii}}$ & $0.90(1)$ & $2.00(2)$ & $2.879(3)$ & $167(3)$ \\
\hline $\mathrm{O} 1-\mathrm{H} 1 \cdots \mathrm{N} 2$ & 0.82 & 1.92 & $2.641(3)$ & 147 \\
\hline \multicolumn{5}{|c|}{3} \\
\hline $\mathrm{N} 4-\mathrm{H} 4 \cdots \mathrm{O} 1^{\mathrm{iii}}$ & $0.90(1)$ & $1.93(1)$ & $2.829(4)$ & 173(4) \\
\hline $\mathrm{N} 1-\mathrm{H} 1 \cdots \mathrm{O} 3$ & $0.90(1)$ & $2.12(2)$ & $3.004(4)$ & $164(3)$ \\
\hline $\mathrm{O} 4-\mathrm{H} 4 \mathrm{~A} \cdots \mathrm{N} 5$ & 0.82 & 1.93 & $2.650(4)$ & 146 \\
\hline $\mathrm{O} 2-\mathrm{H} 2 \cdots \mathrm{N} 2$ & 0.82 & 1.87 & $2.594(4)$ & 146 \\
\hline
\end{tabular}

Symmetry transformation used to generate the symmetry related atoms: (i) $x, y, 1+z$; (ii) $x, 1 / 2-y,-1 / 2+z$; (iii) $1+x, y, z$.

\section{RESULTS AND DISCUSSION}

Structure Description of the Compounds: The molecular structures of compounds 1, 2, and 3 are shown in Figures 1, 2, and 3, respectively. In each compound, the benzohydrazone molecules adopts an $E$ configuration with respect to the $\mathrm{C}=\mathrm{N}$ double bonds. The distances between $\mathrm{C} 11$ and $\mathrm{N} 2$ $[1.287(2) \AA$ in $\mathbf{1}, 1.280(4) \AA$ in $\mathbf{2}]$ in $\mathbf{1}$ and $\mathbf{2}$, as well as those between C8 and N2 [1.282(4) $\AA]$ and C26 and N5 [1.289(4) $\AA]$ in 3, conform them as typical double bonds. The distances between C12 and N3 [1.335(2) $\AA$ in 1, 1.342(4) $\AA$ in 2 ] in 1 and 2, as well as those between C7 and N1 [1.344(4) $\AA]$ and C25 and $\mathrm{N} 4[1.355(5) \AA]$ in $\mathbf{3}$, are intermediate between single and double bonds, due to the conjugation effects of the $\mathrm{C} \cdots \mathrm{N} \cdots \mathrm{N} \cdots \mathrm{C} \cdots \mathrm{O}$ moieties. Hence it can conclude that the molecules of the compounds are in the keto tautomeric form. In 1 , the dihedral angle between $\mathrm{C} 1-\mathrm{C} 6$ and $\mathrm{C} 13-\mathrm{C} 18$ benzene rings is $3.1(2)^{\circ}$
In 2, the dihedral angle between $\mathrm{C} 1-\mathrm{C} 6$ and $\mathrm{C} 13-\mathrm{C} 18$ benzene rings is $72.5(2)^{\circ}$. In 3 , the dihedral angle between $\mathrm{C} 1-\mathrm{C} 6$ and $\mathrm{C} 9-\mathrm{C} 14$ benzene rings is $18.4(2)^{\circ}$; the dihedral angle between $\mathrm{C} 19-\mathrm{C} 24$ and $\mathrm{C} 27-\mathrm{C} 32$ benzene rings is $31.1(2)^{\circ}$. It is notable that the molecule of $\mathbf{1}$, except for the diethylamino group, is much more planar than those of $\mathbf{2}$ and $\mathbf{3}$, which is better attributed to the formation of intramolecular $\mathrm{O} 1-\mathrm{H} 1 \cdots \mathrm{N} 2$ and $\mathrm{N} 3-\mathrm{H} 3 \mathrm{~B} \cdots \mathrm{O} 3$ hydrogen bonds in $\mathbf{1}$ (Table 2). In each molecule of $\mathbf{2}$ and $\mathbf{3}$, there only exists one intramolecular $\mathrm{O}-\mathrm{H} \cdots \mathrm{N}$ hydrogen bond (Table 2). The corresponding bond lengths in the three compounds are comparable to each other, and also within normal values. ${ }^{6,8,11-14}$ For 3, all the bond values are similar to the positional isomer structure. ${ }^{15}$

In the crystal structure of $\mathbf{1}$, molecules are linked through intermolecular $\mathrm{O}-\mathrm{H} \cdots \mathrm{O}$ hydrogen bonds, to form chains running along $c$ axis (Figure 4). In the crystal structure of $\mathbf{2}$, molecules are linked through intermolecular $\mathrm{N}-\mathrm{H} \cdots \mathrm{O}$ hydrogen bonds, to form chains running along $c$ axis (Figure 5). In the crystal 
structure of 3, molecules are linked through intermolecular $\mathrm{N}-\mathrm{H} \cdots \mathrm{O}$ hydrogen bonds, to form chains running along $a$ axis (Figure 6). In addition, $\pi \cdots \pi$ stacking interactions are observed among the benzene rings in the compounds ranging from 4.1 to $4.9 \AA$, as specified in Table 3 .

Antibacterial Activity: The antibacterial activities of the compounds as well as the reference drug are summarized in Table 4 . The results indicated that the compounds show from weak to moderate to effective activities against the growth of the tested strains. It is obvious that the activities of $\mathbf{3}$ are much more effective than those of $\mathbf{1}$ and $\mathbf{3}$, which might be caused by the $\mathrm{Cl}$ substituent of the compound. The Cl-containing compounds have been proved to have interesting biological properties. The activities for $\mathbf{1}$ and $\mathbf{2}$ are not good enough, and show no obvious rules. Compound $\mathbf{3}$ show moderate activities against Staphylococcus aureus and Klebsiella pneumoniae. However, it has effective activity against Escherichia coli, which is even stronger than Tetracycline. In addition, compound $\mathbf{3}$ is more effective than Tetracycline against Candida albicans.

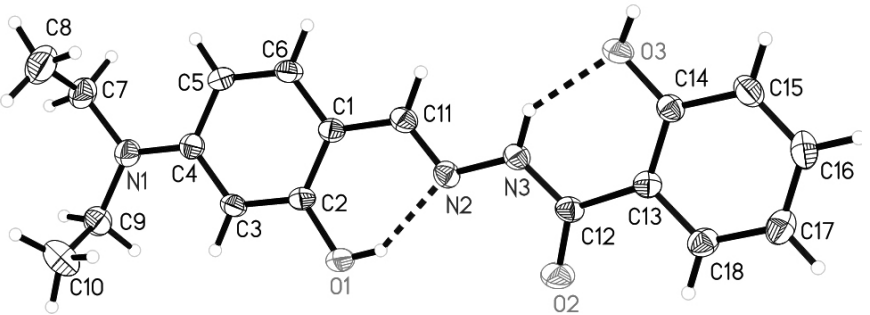

Fig. 1. Thermal ellipsoid plot (30\% probability level) of $\mathbf{1}$ showing the numbering scheme. Hydrogen bonds are shown as dashed lines.

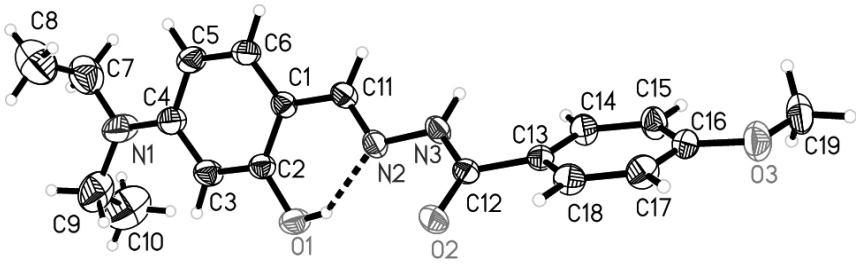

Fig. 2. Thermal ellipsoid plot (30\% probability level) of $\mathbf{2}$ showing the numbering scheme. Hydrogen bond is shown as a dashed line.
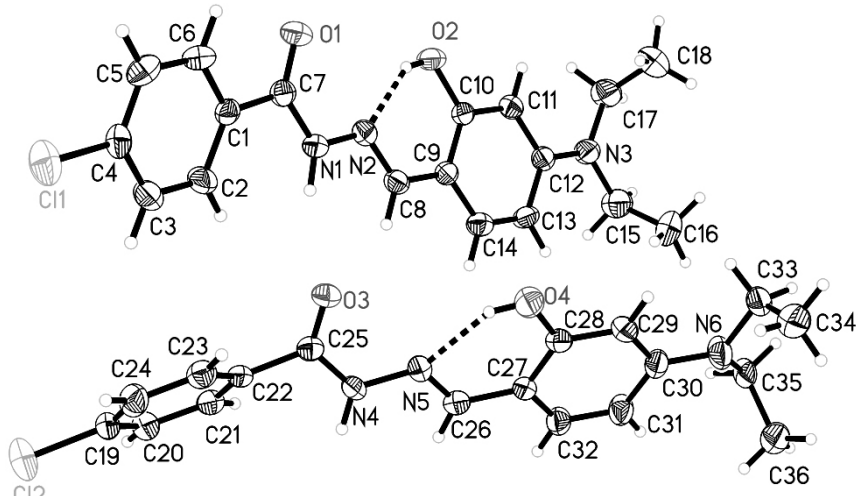

Fig. 3. Thermal ellipsoid plot ( $30 \%$ probability level) of $\mathbf{3}$ showing the numbering scheme. Hydrogen bonds are shown as dashed lines.

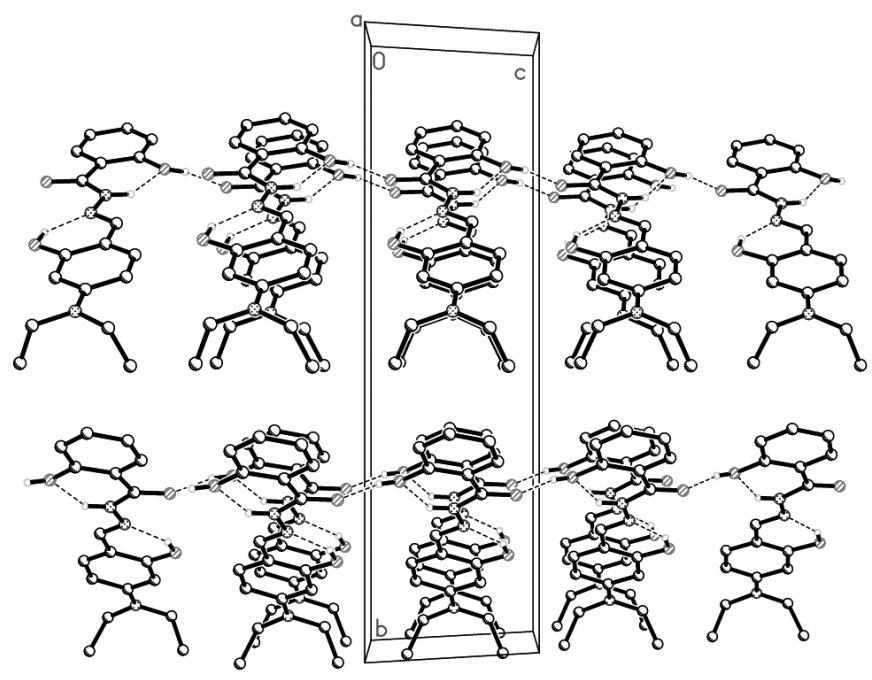

Fig. 4. Packing diagram for 1, viewed along the $a$ axis. Hydrogen bonds are drawn as dashed lines.

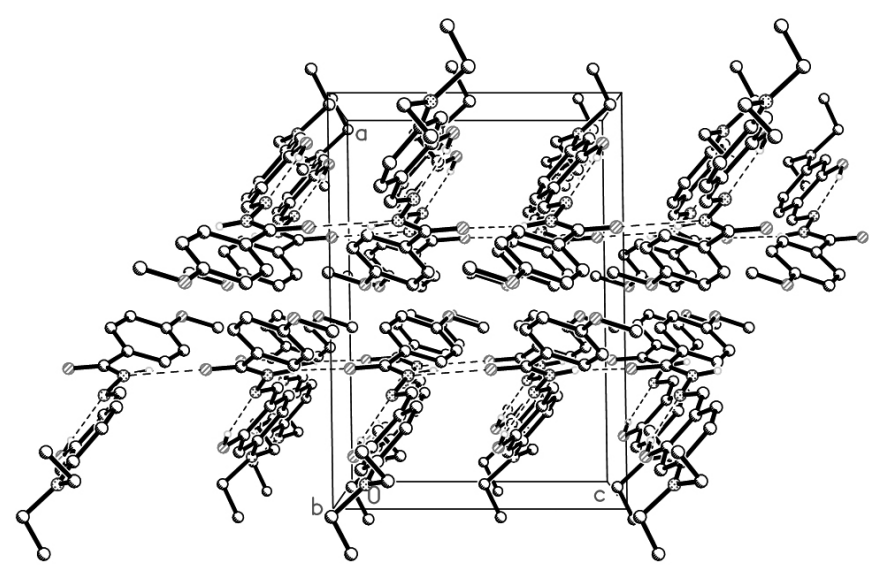

Fig. 5. Packing diagram for $\mathbf{2}$, viewed along the $b$ axis. Hydrogen bonds are drawn as dashed lines.

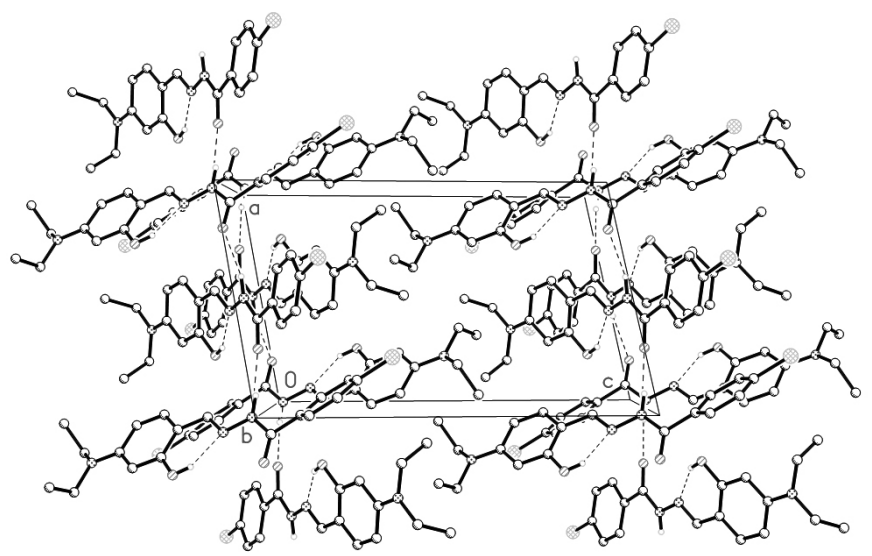

Fig. 6. Packing diagram for $\mathbf{3}$, viewed along the $b$ axis. Hydrogen bonds are drawn as dashed lines. 
TABLE 3. Parameters Between the Planes for the Compounds

\begin{tabular}{|c|c|c|c|c|}
\hline$C g$ & $\begin{array}{c}\text { Distance between ring } \\
\text { centroids }(\AA)\end{array}$ & Dihedral angle $\left(^{\circ}\right)$ & $\begin{array}{c}\text { Perpendicular distance of } \\
C g(\mathrm{I}) \text { on } C g(\mathrm{~J})(\AA)\end{array}$ & $\begin{array}{c}\text { Perpendicular distance of } \\
C g(\mathrm{~J}) \text { on } C g(\mathrm{I})(\AA)\end{array}$ \\
\hline $\mathbf{1}$ & & & & 3.253 \\
\hline$C g 1^{\cdots} C g 2^{\mathrm{iv}}$ & 4.801 & 3.19 & & 3.348 \\
\hline $\mathbf{2}$ & & & & 3.632 \\
\hline$C g 3 \cdots C g 3^{\mathrm{v}}$ & 4.874 & 0.00 & & 3.566 \\
\hline $\mathbf{3}$ & 4.166 & & 3.566 & 2.929 \\
\hline$C g 4 \cdots C g 4^{\mathrm{vi}}$ & 4.853 & 0.02 & 3.781 & \\
\hline$C g 4 \cdots C g 5^{\mathrm{vii}}$ & & 18.97 & & \\
\hline
\end{tabular}

For 1: $C g 1$ and $C g 2$ are the centroids of C1-C2-C3-C4-C5-C6 and C13-C14-C15-C16-C17-C18, respectively. Symmetry code: (iv) $1+x, y, z$. For 2: $C g 3$ is the centroid of C13-C14-C15-C16-C17-C18. Symmetry code: (v) $1-x, 2-y, 2-z$. For 3: Cg4 and Cg5 are the centroids of C1-C2-C3-C4-C5-C6 and C9-C10C11-C12-C13-C14, respectively. Symmetry codes: (vi) $1-x,-y,-z$; (vii) $1-x, 1-y,-z$.

TABLE 4. Antibacterial Activity of the Compounds as MIC Values $(\mu \mathrm{g} / \mathrm{mL})$.

\begin{tabular}{|c|c|c|c|c|}
\hline Test material & Staphylococcus aureus & Escherichia coli & Klebsiella pneumoniae & Candida albicans \\
\hline $\mathbf{1}$ & 32 & 32 & 256 & 128 \\
\hline $\mathbf{2}$ & 16 & 32 & 128 & 256 \\
\hline $\mathbf{3}$ & 4.0 & 1.0 & 8.0 & 64 \\
\hline Tetracycline & 0.22 & 1.5 & 1.2 & $>1024$ \\
\hline
\end{tabular}

\section{CONCLUSION}

Three new benzohydrazone compounds derived from the condensation of 4-diethylaminosalicylaldehyde with 2-hydroxybenzohydrazide, 4-methoxybenzohydrazide, and 4-chlorobenzohydrazide, respectively, in methanol, were prepared and structurally characterized. The preliminary biological tests indicated that 4-chloro- $N$ '-(4-diethylamino-2hydroxybenzylidene)benzohydrazide has effective activity against Escherichia coli, which deserves further study.

\section{SUPPLEMENTARY MATERIAL}

CCDC - 908607 for $\mathbf{1}, 908608$ for $\mathbf{2}$, and 908609 for $\mathbf{3}$ contain the supplementary crystallographic data for this paper. These data can be obtained free of charge at http://www.ccdc.cam.ac.uk/const/retrieving.html or from the Cambridge Crystallographic Data Centre (CCDC), 12 Union Road, Cambridge CB2 1EZ, UK; fax: +44(0)1223-336033 or e-mail: deposit@ccdc.cam.ac.uk.

\section{ACKNOWLEDGEMENTS}

The authors thank the Third Affiliated Hospital of Soochow University for supporting this work.

\section{REFERENCES}

1. M.M. Kamel, H.I. Ali, M.M. Anwar, N.A. Mohamed, A.M. Soliman, Eur J. Med. Chem. 45, 572, (2010).
2. V.S.V. Satyanarayana, M. Rakshit, A. Sivakumar, Asian J. Chem. 23, 1295, (2011).

3. Z.H. Chohan, S.H. Sumrra, M.H. Youssoufi, T.B. Hadda, Eur. J. Med. Chem. 45, 2739, (2010).

4. K. Cheng, Q.-Z. Zheng, Y. Qian, L. Shi, J. Zhao, H.-L. Zhu, Bioorg. Med. Chem. 17, 7861, (2009)

5. A. Ozdemir, G. Turan-Zitouni, Z.A. Kaplancikli, Y. Tunali, J. Enzyme Inhib. Med. Chem. 24, 825, (2009).

6. W.W. Wardakhan, E.M. Samir, J. Chil. Chem. Soc. 57, 1118, (2012).

7. G. Kucukguzel, A. Kocatepe, E. De Clercq, F. Sahin, M. Gulluce, Eur. J. Med. Chem. 41, 353, (2006).

8. M. Zhang, D.-M. Xian, H.-H. Li, J.-C. Zhang, Z.-L. You, Aust. J. Chem. 65, 343, (2012).

9. G.M. Sheldrick, Acta Crystallogr. A64, 112, (2008).

10. A. Barry, Procedures and theoretical considerations for testing antimicrobial agents in agar media. in: Lorian (Ed.), Antibiotics in Laboratory Medicine, $5^{\text {th }}$ ed. Williams and Wilkins, Baltimore, (1991).

11. R.B.N. Bessy, K.M.R. Prathapachandra, E. Suresh, Struct. Chem. 17, 201, (2006).

12. Y.-M. Cui, Y.-J. Cai, W. Chen, J. Coord. Chem. 64, 1385, (2011).

13. Q.-Y. Zhu, Y.-J. Wei, F.-W. Wang, Polish J. Chem. 83, 1233, (2009).

14. K. Pyta, P. Przybylski, A. Huczyński, A. Hoser, K. Wozniak, W. Schilf, B. Kamienski, E. Grech, B. Brzezinski, J. Mol. Struct. 970, 147, (2010).

15. T.-Y. Li, B.-B. Li, Acta Crystallogr. E67, o383, (2011). 